\title{
Pencegahan Stunting Melalui Penguatan Peran Kader Gizi dan Ibu Hamil Serta Ibu Menyusui Melalui Participatory Hygiene and Sanitation Transformation (PHAST)
}

\author{
Dewi Rokhmah ${ }^{1}$, Nur Fitri Widya Astuti ${ }^{2}$, Globila Nurika ${ }^{3}$, \\ Dewa Ngakan Gde Wahyu Mahatma Putra ${ }^{4}$, Khoiron ${ }^{5}$ \\ ${ }^{1}$ Departement Promosi Kesehatan dan Ilmu Perilaku Fakultas Kesehatan Masyarakat, Universitas Jember \\ ${ }^{2}$ Departement Gizi Masyarakat, Fakultas Kesehatan Masyarakat Universitas Jember \\ ${ }^{3,5}$ Departement Kesehatan Lingkungan Fakultas Kesehatan Masyarakat, Universitas Jember \\ Email: dewirokhmah@unej.ac.id
}

\begin{abstract}
Stunting is a chronic nutritional problem caused by lack of nutrition for a long time. Sumberwringin Village is one of the villages in Bondowoso Regency with a fairly high number of cases of stunting under five and is one of the fostered villages of the University of Jember that requires assistance in resolving public health problems, especially regarding the handling of nutrition and stunting problems. Food and nutrition insights from community program actors, such as nutrition cadres, pregnant women, and breastfeeding mothers play an important role in efforts to prevent and improve stunting problems in Indonesia.The aim of the implementation of this community service activity is to increase the competence (cognitive, affective, and psychomotor) of posyandu cadres in providing education to the community about stunting prevention based on community participation through changes in personal hygiene and sanitation, and preventing pregnant women and breastfeeding mothers gave birth to a stunting baby. The subjects of the training activities were 34 pregnant women and mothers under five in Sumberwringin Village, Sumberwringin District, Bondowoso Regency. This activity was carried out by means of lectures and discussion questions and answers regarding the material of Stunting Prevention with the PHAST Method. The results of this activity indicated that there was a significant difference in the level of knowledge among all participants before and after being given material related to stunting and environmental health with an average increase of 30 points. This activity can be concluded that community service activities in preventing stunting through Participatory Hygiene and Sanitation Transformation (PHAST) are able to increase participants' knowledge about Stunting Prevention with the PHAST Method.
\end{abstract}

Keywords: Stunting, Participatory Hygiene and Sanitation Transformation, PHAST.

\begin{abstract}
Abstrak
Stunting merupakan masalah gizi kronis yang disebabkan oleh kurangnya asupan gizi dalam waktu yang lama. Desa Sumberwringin merupakan salah satu desa binaan dari Universitas Jember yang berada di Kabupten Bondowoso dengan penemuan kasus balita stunting yang cukup tinggi sehingga memerlukan pendampingan dalam penyelesaian masalah kesehatan masyarakat khususnya mengenai penanganan masalah gizi dan stunting. Wawasan pangan dan gizi pelaku program masyarakat, seperti kader gizi, ibu hamil, dan ibu menyusui berperan penting dalam upaya pencegahan dan perbaikan masalah stunting di Indonesia. Tujuan dari pelaksanaan penelitianini adalah untuk meningkatkan kompetensi (kognitif, afektif, dan psikomotor) kader posyandu dalam memberikan penyuluhan bagi masyarakat tentang pencegahan stunting berbasis partisipasi masyarakat melalui perubahan hygiene personal dan sanitasi, serta mencegah bumil dan ibu menyusui (Busui) melahirkan bayi stunting. Subjek dari kegiatan pelatihan yang dilakukan adalah ibu hamil dan ibu balita yang berjumlah 34 orang di Desa Sumberwringin, Kecamatan Sumberwringin, Kabupaten Bondowoso. Kegiatan ini dilakukan dengan cara ceramah dan diskusi tanya jawab mengenai materi Pencegahan Stunting dengan Metode PHAST. Hasil kegiatan ini menunjukkan bahwa terdapat perbedaan yang bermakna untuk tingkat pengetahuan pada seluruh peserta sebelum dan setelah diberikan materi terkait stunting dan kesehatan lingkungan dengan rata-rata peningkatan yaitu 30 poin. Dapat disimpulkan bahwa penelitiandalam mencegah stunting melalui
\end{abstract}


Participatory Hygiene and Sanitation Transformation (PHAST) mampu meningkatkan pengetahuan peserta mengenai Pencegahan Stunting dengan Metode PHAST.

Kata kunci: stunting, Participatory Hygiene and Sanitation Transformation, PHAST.

\section{PENDAHULUAN}

Tim Nasional Percepatan Penanggulangan Kemiskinan Republik Indonesia pada tahun 2016 telah merilis 100 (seratus) kabupaten/kota untuk anak stunting yang didalamnya terdapat sepuluh kabupaten/kota di Propinsi Jawa Timur, antara lain Kabupaten Lamongan, Nganjuk, Bondowoso, Sumenep, Probolinggo, Pamekasan, Jember, Bangkalan, Sampang, dan Lumajang. Angka prevalensi stunting di Jawa Timur mencapai angka 56,38\% di Kabupaten Bondowoso, 52,44\% di Kabupaten Sumenep, 49,43\% di Kabupaten Probolinggo, 48,87\% di Kabupaten Lamongan, 44,60\% di Kabupaten Pamekasan, 44,33\% di Kabupaten Nganjuk, 44,10\% di Kabupaten Jember, 43,21\% di Kabupaten Bangkalan, 41,46\% di Kabupaten Sampang dan Kabupaten Lumajang sebesar 41,31\%. Angka ini berada jauh diatas angka rata-rata nasional 37,2\%. Pada Tahun 2018 melalui Dinas Kesehatan Kabupaten Bondowoso, pada bulan timbang menunjukkan pada Bulan Februari 2019, jumlah balita dengan stunting mencapai $22,88 \%$ dari total 45.956 yang hadir.

Faktor penyebab langsung terjadinya stunting adalah ketidakseimbangan gizi/faktor gizi dalam makanan yang dikonsumsi dan terjangkitnya penyakit infeksi. Asupan makanan yang tidak adekuat, kualitas makanan yang rendah, peningkatan kesakitan, atau kombinasi dari faktor-faktor tersebut yang terjadi pada periode waktu yang lama. Budaya, tradisi, atau kebiasaan yang ada dalam masyarakat seperti pantangan makan, dan pola makan yang salah dapat mengakibatkan munculnya masalah gizi terutama bagi balita. Hal ini dapat berdampak terhadap pertumbuhan dan perkembangan balita (Adriani \& Wirjatmadi, 2014). Menurut UNICEF faktor yang berperan terhadap kejadian stunting adalah faktor lingkungan, penyakit infeksi berulang, morbiditas meningkat, pengasuhan anak yang tidak memadai, sanitasi yang buruk, akses terhadap pelayanan kesehatan yang kurang, pendapatan yang rendah, pendudukan dan pengetahuan gizi, serta kesehatan ibu yang minim.

Desa Sumberwringin merupakan salah satu desa di Kabupten Bondowoso dengan penemuan kasus balita stunting yang cukup tinggi dan merupakan salah satu desa binaan dari Universitas Jember yang memerlukan pendampingan dalam penyelesaian masalah kesehatan masyarakat khususnya mengenai penanganan masalah gizi dan stunting. Di wilayah ini terdapat sungai yang masih digunakan untuk sarana Mandi Cuci dan Kakus (MCK) warga. Selain itu, pengetahuan warga dalam perilaku personal higene dan sanitasi lingkungan masih sangat rendah. Dalam pelaksanaan Bulan Timbang di Desa Sumberwringin tahun 2019, terdapat 327 balita yang mengikuti kegitan tersebut. Dimana berdasarkan jenis kelamin, terdiri dari 163 balita laki-laki $(49,8 \%)$ dan perempuan sebanyak 164 balita $(50,2 \%)$. Sedangkan posyandu terbanyak dengan balita yang ditimbang adalah posyandu Aster 1 sebanyak 98 Balita (30\%), dan yang paling sedikit berasal dari posyandu Aster 8 sebanyak 11 orang (3\%). Dari hasil penimbangan dapat diketahui bahwa, di Desa Sumberwringin terdapat 199 balita $(60,86 \%)$ memiliki masalah gizi Sedangkan hanya sebanyak 128 balita $(39,14 \%)$ yang sehat.

Berdasarkan data dan penjelasan tersebut maka penelitian di Desa Sumberwringin, Kabupaten Bondowoso perlu dilakukan sebagai bentuk pemberdayaan masyarakat khususnya untuk ibu hamil dan ibu menyusui dari keluarga rawan gizi di kawasan endemik stunting dan upaya dalam mencegah meningakatnya angka stunting melalui Participatory Hygiene and Sanitation Transformation (PHAST) di Desa Sumberwringin, Kabupaten Bondowoso. Kegiatan ini dilakukan dengan tujuan untuk meningkatkan kompetensi (kognitif, afektif, dan psikomotor) kader posyandu dalam memberikan penyuluhan bagi masyarakat tentang pencegahan stunting berbasis partisipasi masyarakat melalui perubahan hiegene personal dan sanitasi, serta mencegah bumil dan ibu menyusui (Busui) yang melahirkan bayi stunting.

\section{METODE PELAKSANAAN}

Kegiatan penelitian ini dilaksanakan melalui pelatihan dan pendampingan kader gizi, ibu hamil, dan ibu menyusui dari keluarga rawan gizi di Desa Sumberwringin, Kecamatan Sumberwringin dengan metode Participatory Hygiene And Sanitation Transformation (PHAST), sehingga dapat mengatasi permasalahan terkait Pencegahan stunting pada balita di 1000 HPK. Kegiatan pelatihan dan pendampingan ini dilakukan dengan cara ceramah dan diskusi tanya jawab mengenai materi Pencegahan Stunting dengan Metode PHAST yang dilaksanakan di Balai Desa Sumberwringin, Kecamatan Sumberwringin, Kabupaten Bondowoso. Peserta dari kegiatan ini adalah 34 orang yang terdiri dari ibu hamil dan ibu balita.

Evaluasi kegiatan penelitian ini dilakukan dengan pengukuran tingkat pengetahuan dan tindakan sasaran melalui pre dan post test. Pengukuran tingkat pengetahuan dilakukan dengan memberikan 10 pertanyaan yang diberikan sebelum dan setelah pemberian materi. Selain pertanyaan juga dilakukan pengisian data karakteristik peserta yang terdiri dari nama, usia, pekerjaan, dan keterangan apakah peserta 
merupakan ibu hamil atau ibu balita. Kemudian data yang telah dikumpulkan dianalisis dengan menggunakan analisis univariat untuk mengetahui gambaran karakteristik peserta dan bivariat dengan menggunakan wilcoxon test untuk mengetahui apakah terdapat perbedaan tingkat pengetahuan sebelum dan setelah diberikan materi. Seluruh pengolahan data dilakukan dengan menggunakan software STATA versi 13.1 .

\section{HASIL DAN PEMBAHASAN}

Gambaran Lokasi Kegiatan

Sebelum memlakukan kegiatan pendidikan kesehatan, tim melakukan survey pendahuliusan dengan melakukan weawancara dengan perangkat desa setempat. Dari hasil wawancara dan kunjungan ke mitra yaitu Kepala Desa Sumberwringin yang dikuatkan oleh hasil wawancara dengan Bidan Desa Sumberwringin menyebutkan bahwa kasus stunting yang ditemukan di wilayah kerjanya bersal dari keluarga miskin yang sangat minim dalam akses sanitasi yang memadai. Yaitu tidak memiliki akses sarana air bersih dan tidak memiliki jamban di rumah. Hal ini seperti hasil observasi tim pada saat melakukan kunjungan ke lokasi tempat tinggal mitra. Berikut ini dokumentasi kondisi sanitasi keluarga yang memiliki anak dalam kategori stunting :
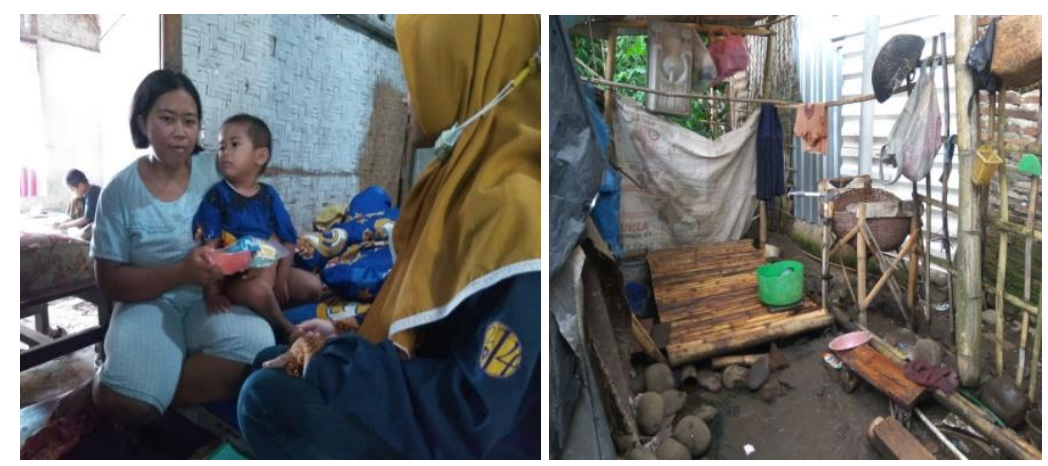

Gambar 1. Keluarga yang memiliki Balita Stunting bersama ketua Tim Pengusul dan Kondisi jamban serta sarana air bersih yang minim

Balita merupakan usia dimana anak sedang mengalami proses pertumbuhan yang relatif pesat dan membutuhkan asupan gizi yang relatif besar. Perubahan yang terjadi pada balita dari waktu ke waktu merupakan petunjuk awal perubahan status gizi balita. Saat periode 6 bulan, balita yang berat badannya tidak mengalami kenaikan dua kali berisiko mengalami underweight 12,6 kali dibandingkan pada balita yang berat badannya naik terus. Penelitian dari jurnal internasional Leonor rodriguez dalam (Pratiwi et al, 2015), menyebutkan kurangnya asupan protein dan kalori adalah alasan yang mendasari meningkatnya kerentanan terhadap penyakit infeksi. Penyakit infeksi yang sering ditemukan pada nak balita adalah diare yang disebabkan oleh kurangnya sarana air bersih serta sanitasi yang buruk dalam pembuangan feses.

Selain itu, pendukung terjadinya underweight pada balita adalah keadaan keluarga yang memburuk yaitu rendah sosial ekonomi, rendah pendidikan dan kurangnya hasil pertanian, sehingga menyebabkan kurangnya ketersediaan makanan dalam rumah tangga. Kondisi ini sering dijumpai pada keluarga miskin yang rendah terhadap akses pendidikan dan informasi kesehatan. Hal ini seperti hasil kunjungan tim PDB ke lokasi Mitra bahwa masih ditemukan keluarga miskin dan keluarga rawan gizi yang tidak memiliki sarana air bersih dan jamban yang memadai. Hal ini seperti pada dokumentasi berikut ini:
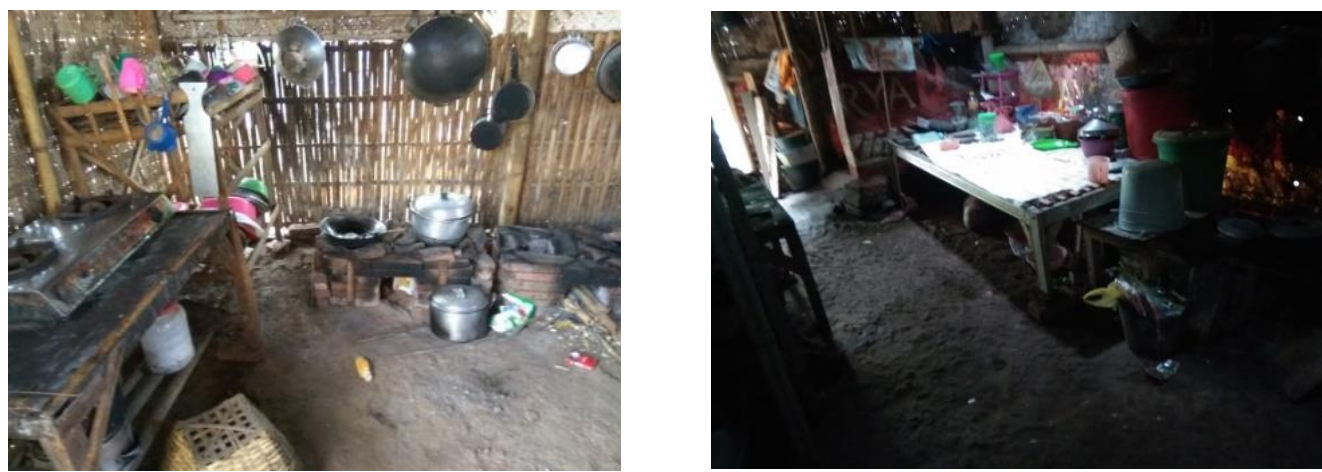

Gambar 2. Kondisi rumah dan dapur warga yang sangat minim dari sarana air bersih 


\section{Karakteristik Demografi Sasaran Kegiatan}

Berdasarkan hasil analisis, lebih dari 50\% peserta merupakan ibu yang memiliki balita, berusia dalam rentang 25-34 tahun, dan merupakan ibu rumah tangga (Tabel.1)

Tabel 1. Karakteristik peserta

\begin{tabular}{llr}
\hline & \multicolumn{2}{c}{ Jumlah } \\
\cline { 2 - 3 } & $\mathrm{n}$ & $\%$ \\
\hline Kelompok pesrta & 13 & 38,24 \\
$\quad$ Ibu hamil & 18 & 52,94 \\
$\quad$ Ibu balita & 3 & 8,82 \\
$\quad$ Ibu hamil dan Ibu balita & & \\
Usia (Tahun) & 12 & 35,29 \\
15-24 & 17 & 50,00 \\
25-34 & 5 & 14,71 \\
$>34$ & & \\
Status pekerjaan & 1 & 2,94 \\
$\quad$ Bekerja & 33 & 97,06 \\
$\quad$ Tidak bekerja & 34 & 100,00 \\
\hline Total & & \\
\hline
\end{tabular}

Berdasarkan hasil penelitian yang dilakukan oleh Candra (2013), usia ibu yang terlalu muda atau terlalu tua pada waktu hamil dapat menyebabkan stunting pada anak terutama karena faktor psikologis. Ibu yang terlalu muda biasanya belum siap dengan kehamilannya dan belum memiliki pengetahuan yang cukup tentang bagaimana menjaga dan merawat kehamilan. Sedangkan ibu yang usianya terlalu tua bisanyanya terjadi penurunan stamina dan semangat dakam merawat kehamilannya juga ikut berkurang. Agustiningrum (2016) menyebutkan bahwa usia ibu berperan sebagai faktor psikologis ibu terhadap anak seperti penerimaan kehamilan anak yang akan berpengaruh pada pola pengasuhan anak termasuk dalam pola asuh pemberian makanan kepada anak. Selain itu, faktor psikologis ibu ini juga berpengaruh terhadap pertumbuhan janin. Menurut penelitian yang dilakukan oleh Arini, et al. (2020) usia ibu saat melahirkan merupakan salah satu faktor yang mempengaruhi kejadian stuting pada anak. Ibu yang melahirkan pada usia muda memiliki risiko terjadinya kelahiran secara prematur dan berisiko mengalami infeksi yang merupakan salah satu faktor terjadinya stunting.

Penelitian yang dilakukan oleh Faye, et al. (2019) di Afrika Selatan menyebutkan bahwa ibu yang melahirkan diusia 35 tahun keatas memiliki risiko lebih kecil melahirkan anak stunting daripada ibu yang melahirkan pada usia 18 tahun kebawah. Hal ini karena ibu yang berusia muda sebagian bedar kekurangan sumber daya dan pengalaman untuk memenuhi kebutuhan anak mereka termasuk nutrisi dan perawatan kesehatan. Selain itu, penelitian yang dilakukan di Pakistan oleh Khan, et al., (2019) juga menyebutkan bahwa ibu yang melahirkan pada usia $<20$ tahun berisiko memiliki anak stunting 0,76 kali lebih besar. Sedangkan menurut penelitian yang dilakukan oleh Singh, et al. (2017) menyebutkan bahwa ibu yang melahirkan pada usia 18 tahun keatas lebih berisiko memiliki anak stunting 0,52 kali daripada ibu yang melahirkan diusia 17 tahun. Usia ibu saat melahirkan mempunyai hubungan yang signifikan terhadap kejadian stunting pada anak (Kismul, et al., 2018).

Peran Kader Gizi Dan Ibu Hamil Serta Ibu Menyusui Dari Keluarga Rawan Gizi Melalui Participatory Hygiene And Sanitation Transformation (PHAST)

Dari analisis situasi dan permasalahan yang terjadi pada mitra maka solusi yang dapat kami tawarkan melalui program pelatihan dan pendampingan terintegrasi dalam pencegahan Stunting melalui Penguatan Peran Kader Gizi Dan Ibu Hamil Serta Ibu Menyusui Dari Keluarga Rawan Gizi dengan metode Participatory Hygiene And Sanitation Transformation (PHAST). Program ini dilaksanakan dengan cara menjalin kerja sama antara Tim dengan Kepala Desa Sumberwringin serta Bidan Desa Sumberwringin Kecamatan Sumberwringin sebagai mitra. Tim bertindak sebagai pelatih (trainer) dan pendamping, sedangkan kader gizi, bumil dan busui dari keluarga rawan gizi berperan sebagai peserta pelatihan.

Dengan pelaksanaan program pelatihan dan pendampingan kader gizi, Bumil dan ibu menyusui dari keluarga rawan gizi di Desa Sumberwringin Kecamatan Sumberwringin dengan metode Participatory Hygiene And Sanitation Transformation (PHAST), sehingga dapat mengatasi 
permasalahan terkait Pencegahan stunting pada balita di 1000 HPK, serta diharapkan dapat : (1) Meningkatnya jumlah kader Posyandu yang memiliki ketrampilan dalam mencegah stunting berbasis perubahan Hiegene personal dan Sanitasi; (2) Meningkatnya rasa percaya diri kader posyandu sebagai penyuluh Pencegahan Stunting berbasis perubahan Hiegene personal dan Sanitasi; (3) Meningkatnya ketrampilan Kader posyandu, Bumil dan Busui dari keluarga rawan gizi dengan balita stunting memiliki keterampilan untuk mengolah makanan yang sesuai standar Hiegene personal dan Sanitasi sebagai upaya pencegahan stunting; (4) Meningkatnya ketrampilan Kader gizi, bumil dan busui dari keluarga dengan balita stunting mendapatkan wawasan dan teknologi tepat guna untuk menyiapkan menu sehat melalui pemenuhan kebutuhan nutrisi ibu dan bayi yang sesuai syarat Hiegene personal dan sanitasi makanan. Berikut ini adalah dokumentasi selama kegiatan :

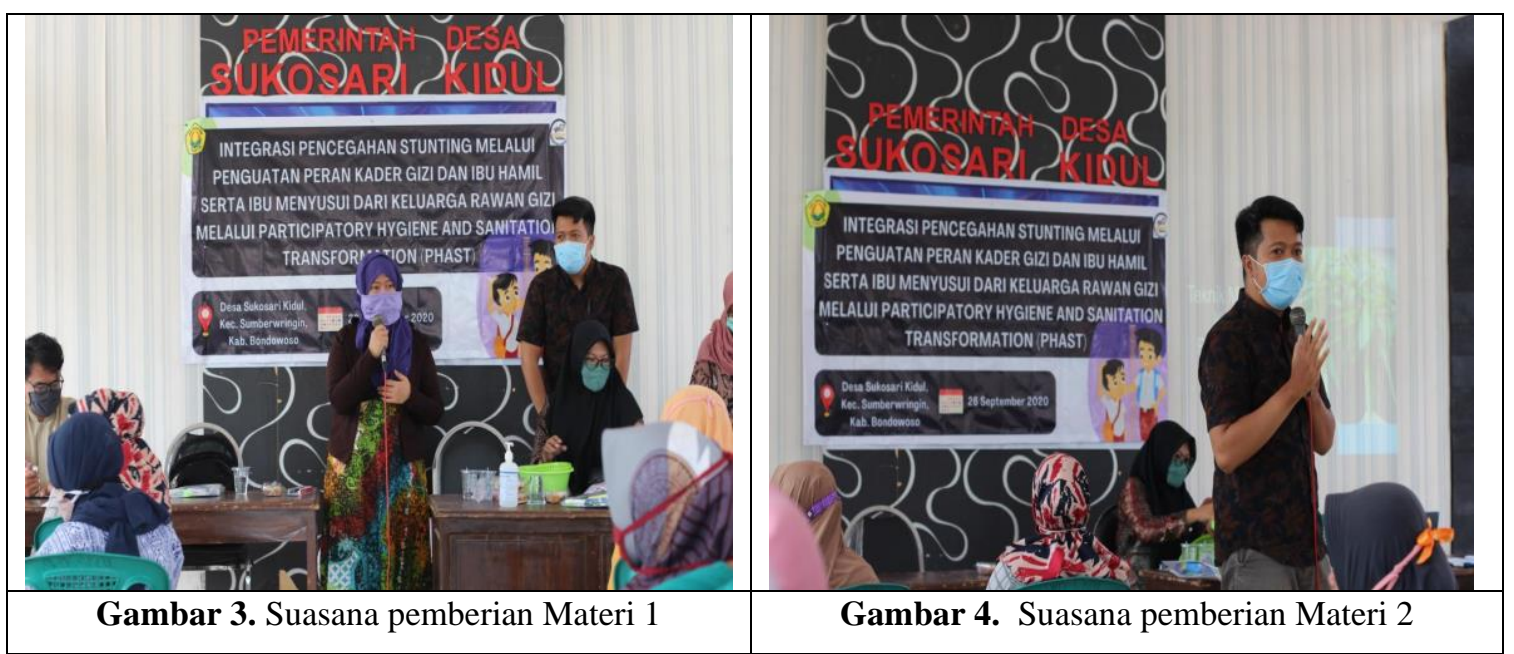

Hasil analisis Wilcoxon menunjukkan bahwa terdapat perbedaan yang bermakna untuk tingkat pengetahuan pada seluruh peserta sebelum dan setelah diberikan materi terkait stunting dan kesehatan lingkungan dengan rata-rata peningkatan yaitu 30 poin. Setelah dilakukan stratifikasi pada kelompok peserta, hasil analisis menunjukkan bahwa kelompok ibu hamil dan kelompok ibu balita memiliki perbedaan yang bermakna pada tingkat pengetahuan sebelum dan setelah diberikan materi. Hasil analisis dapat dilihat secara lengkap pada Tabel 2.

Tabel 2. Hasil analisis peserta sebelum dan setelah diberikan materi penyuluhan

\begin{tabular}{llcccc}
\hline Kelompok perserta & $\mathrm{n}$ & \multicolumn{4}{c}{ Rata-rata \pm SD } \\
\cline { 3 - 6 } & & Pre-test & Post-test & $\Delta \mathrm{p}$ & P-value \\
\hline Semua & 34 & $50,59 \pm 25,34$ & $81,18 \pm 23,97$ & $30,59 \pm 26,85$ & $<0,001^{*}$ \\
Ibu hamil & 13 & $55,38 \pm 26,34$ & $79,23 \pm 20,19$ & $23,85 \pm 29,87$ & $0.018^{*}$ \\
Ibu balita & 18 & $50,56 \pm 24,13$ & $86,11 \pm 20,04$ & $35,56 \pm 25,02$ & $<0.001^{*}$ \\
Ibu hamil dan Ibu balita & 3 & $30,00 \pm 26,46$ & $60,00 \pm 51,96$ & $30,00 \pm 26,46$ & 0,166 \\
\hline
\end{tabular}

Keterangan : *signifikan pada $\mathrm{p}<0.05, \Delta \mathrm{p}=$ selisih nilai pre-test dan post-test

Menurut penelitian yang dilakukan oleh Aridiyah, et al. (2015) tingkat pengetahuan ibu mengenai gizi merupakan salah satu faktor yang dapat mempengaruhi terjadinya stunting pada anak balita baik di daerah pedesaan maupun perkotaan. Pengetahuan mengenai gizi merupakan proses awal dalam perubahan perilaku peningkatan status gizi, sehingga pengetahuan merupakan faktor internal yang mempengaruhi perunahan perilaku. Pengetahuan ibu tentang gizi akan menentukan perilaku ibi dalam penyediaan makanan untuk anak ibu dengan pengetahuan gizi yang baik dapat menyediakan makanan dengan jenis dan jumlah yang tepat untuk mendukung pertumbuhan dan perkembangan balita.

Hapsari (2018) juga menyebutkan bahwa pengetahuan ibu tentang gizi balita sangat berpengaruh terhadap petumbuhan dan perkembangan balita. Pengetahuan ibu ini dapat dipengaruhi oleh beberapa faktor diantaranya umur yang akan menentukan proses perkembangan mental ibu, intelegensi atau kemampuan untuk belajar dan berpikir dalam penyesuaian diri di keadaan yang baru, dan lingkungan dimana ibu dapat mempelajari hal baik dan buruk. Selain itu, budaya yang ada disekitar ibu juga memiliki peranan penting dalam perkembangan pengetahuan ibu.

Menurut penelitian yang dilakukan oleh Rahayu \& Khairiyah (2014) pengetahuan ibu dapat dipengaruhi oleh tingkat pendidikan ibu. Tingkat pendidikan ibu berpengaruh pada pemahaman ibu dalam mendidik dan mengarahkan anak pada pemberian makan bergizi seimbang sehingga dapat menunjang pertumbuhan dan perkembangan anak kearah peningkatan derajat kesehatan. Hal ini terkait peranan ini 
dalam pembentukan kebiasaan makan anak. Selain itu, tingkat pendidikan dan pengetahuan ibu juga berpengaruh pada pola asuh dalam pemilihan jenis makanan. Pengetahuan yang dimiliki ibu tersebut akan dipraktikkan dalam proses perawatan anak yang akan berimbas pada status gizi dan kesehatan anak yang lebih baik.

Sebagai upaya peningkatan pengetahuan ibu dapat dilakukan dengan pemberian informasi atau pengalaman kepada ibu. Pemberian informasi dapat dilakukan dengan pemberian penyuluhan atau pengalaman yang bersifat langsung maupun tidak langsung yang akan mendorong pengetahuan ibu menjadi lebih baik. Upaya ini dapat dilakukan dengan melibatkan bidan atau tenaga kesehatan setempat yang akan melakukan pendampingan dengan tetap memberikan edukasi dan pelatihan yang memperhatikan adat dan budaya yang selama ini dijunjung oleh masyarakat setempat. Selain itu, pendekatan dengan menggunakan konselor sebaya (peer councellor) seperti melibatkan kader-kader muda dari kalangan ibu-ibu yang ada di masyarakat. konselor inilah yang nantinya akan memberikan konseling kepada ibu lainnya untuk mendukung mereka dalam memperhatikan pemenuhan gizi anak (Nurbaya, 2020).

Pendekatan budaya dan agama merupakan juga faktor yang signifikan dalam mendorong perubahan perilaku dalam masyarakat terkait dengan gizi. Hasil penelitian yang dilakukan oleh Nur, et al. (2020) menunjukkan bahwa peran pemuka agama dan pemuka masyarakat sangat penting dalam membantu mensosialisasikan isu gizi buruk dan stunting melalui perspektif agama kepada masyarakat. Hal ini karena tokoh-tokoh tersebut menjadi agen yang berpengaruh dalam mendorong perubahan perilaku dan menjadi rujukan nilai yang mendasari perubahan pengetahuan, sikap, dan perilaku masyarakat. Selain peran eksternal dari toko-tokoh masyarakat tersebut, perempuan atau ibu pelu terus diberdayakan untuk meningkatkan status gizi baik anak-anak dan anggota keluarga lainnya.

Menurut penelitian yang dilakukan oleh Khitam (2019) pendekatan sosial juga dapat dilakukan dalam meningkatkan pengetahuan dan informasi pencegahan stunting melalui pelatihan kader. Pelatihan yang diadakan dapat berbentuk seminar dan menundang pemateri yang berkompeten untuk memberikan pengetahuan dan informasi pencegahan stunting. FGD (Focus Group Discussion) antara kader dengan stakeholder dapat dilakukan untuk memberikan hasil dari pelatihan kepada masyarakat. Selain itu, kader juga dapat melaksanakan kegiatan non formal sebagai pendekatan sosial untuk pencegahan stunting. Pendekatan sosial dapat dilakukan memalui kegiatan-kegiatan yang biasanya ada di tengah masyarakat seperti kegiatan keagamaan untuk melakukan penyuluhan, melakukan kampanye baik digital dengan bentuk konten media sosial, serta kampanye kreatif bentuk non digital dengan membuat event lomba seperti lomba memasak bagi ibu-ibu dengan tema pencegahan stunting.

\section{KESIMPULAN}

Kesimpulan dari pelaksanaan penelitian pada kader gizi, ibu hamil, dan ibu menyusui dari keluarga rawan gizi di Desa Sumberwringin, Kecamatan Sumberwringin dengan metode Participatory Hygiene And Sanitation Transformation (PHAST) berjalan dengan lancar. menunjukkan bahwa terdapat perbedaan yang bermakna untuk tingkat pengetahuan pada seluruh peserta sebelum dan setelah diberikan materi terkait stunting dan kesehatan lingkungan dengan rata-rata peningkatan yaitu 30 poin. Penelitian dalam mencegah stunting melalui Participatory Hygiene and Sanitation Transformation (PHAST) mampu meningkatkan pengetahuan dan ketrampilan peserta mengenai Pencegahan Stunting dengan Metode PHAST.

\section{UCAPAN TERIMA KASIH}

Ucapan terima kasih tim penulis sampaikan kepada Universitas Jember dan Lembaga Penelitian dan Pengabdian Kepada Masyarakat Universitas Jember atas pendanaan kegiatan penelitian ini. Selain itu, ucapan terima kasih juga disampaikan kepada para responden penelitian, Bidan Desa dan Kepala Desa Sumberwringin Bondowoso atas partisipasi dan dukungannya dalam pelaksanaan kegiatan penelitian ini.

\section{DAFTAR PUSTAKA}

Agustiningrum, T., 2016. Hubungan Karakteristik Ibu dengan Kejadian Stunting pada Balita Usia 24-59 di Wilayah Kerja Puskesmas Wonosari 1. Yogyakarta: Fakultas Ilmu Kesehatan Universitas "Aisyiyah Yogyakarta.

Aridiyah, F. O., Rohmawati, N. \& Ririanty, M., 2015. Faktor-Faktor yang Mempengaruhi Kejadian Stunting pada Anak Balita di Wilayah Pedesaan dan Perkotaan. e-Jurnal Pustaka Kesehatan, Volume 3(1): 163-170.

Arini, D., Chabibah, N. \& Agustin, M. A., 2020. Analisa Determinan Sosial Demografi Ibu terhadap Kejadian Stunting pada Anak Usia Toddler di Wilayah Puskesmas Kenjeran Surabaya. Journal Of Health Science, Volume 5(1): 1-10 
Candra, A., 2013. Hubungan Underlying Factors dengan Kejadian Stunting pada Anak 1-2 Tahun. Diponegoro Journal of Nutrition and Health, 1-12.

Efriyadi, O., 2018. Pengaruh Perbedaan Jenis Media Tanam Hidroponik terhadap Pertumbuhan Pakcoy (Brassica rapa) dan Kangkung (Ipomoea aquatic). Proceeding of The URECOL, 675-681.

Faye, C. M., Fonn, S. \& Levin, J., 2019. Factors Associated with Recovery from Stunting among Underfive Children in Two Nairobi Informal Settlements. PLOS ONE, Volume 14(4): 1-18. https://doi.org/10/1371/journal.pone.0215488.

Hapsari, W., 2018. Hubungan Pendapatan Keluarga, Pengetahuan Ibu tentang Gizi, Tinggi Badan Orang Tua, dan Tingkat Pendidikan Ayah dengan Kejadian Stunting pada Anak Umur 12-59 Bulan. Surakarta: Fakultas Kedokteran, Universitas Muhammadiyah Surakarta.

Indrianasari, Y. and Suparti, M., 2016. Pertumbuhan Tanaman Selada (Lactuca Sativa L.) Secara Hidroponik Pada Media Pupuk Organik Cair Dari Kotoran Kambing Dan Kotoran Kelinci (Doctoral dissertation, UNIVERSITAS MUHAMMADIYAH SURAKARTA).

Khan, S., Zaheer, S. \& Safdar N. F, 2019. Determinants of Stunting Underweight and Wasting among children <5 years of age: evidence from 2012-2013 Pakistan Demographic and Health Survey. BMC Public Health, Volume 19:1-6.

Kismul, H., Acharya, P., Mapatono, M. A. \& Hatloy, A., 2018. Determinants of Chilhood Stunting in the Democratic Republic of Congo: Further Analysis of Demographic and Health Survey 20132014. BMC Public Health, Volume 18(1): 1-15. https://doi.org/10.1186/s12889-017-4621-0

Khitam, M. C., 2019. Pengembangan Kapasitas Organisasi Perempuan Fatayat dalam Pencegahan Stunting Melalui Pendekatan Sosial. Empowering: Jurnal Pengabdian Masyarakat, Volume 3: 53-57.

Nurbaya, 2020. Gambaran Praktik Pemberian Makanan Prelakteal pada Bayi dan Peran Dukun Anak di Masyarakat Adat Kaluppini. Jurnal Ilmiah Permas, Volume 11(1): 41-50.

Nursandi, J.N.J., 2018. Budidaya Ikan Dalam Ember "Budikdamber" dengan Aquaponik di Lahan Sempit. In Prosiding Seminar Nasional Pengembangan Teknologi Pertanian.

Nurilmala, M., Nurjanah., \& Utama, R.H.(2009). Kemunduran Mutu Ikan Lele Dumbo. Jurnal Pengolahan Hasil Perikanan Indonesia 12 (1) 1-16 Tahun 2009 Institut Pertanian Bogor.

Nur, T. H., Setyowati, H. N. \& Rosemary, R., 2020. Rumah Gizi 'Aisyiyah: Komunikasi Kesehatan Dengan Pendekatan Agama-Budaya. Jurnal Komunikasi Global, Volume 9(1): 141-161.

Rahayu, A. \& Khairiyah, L., 2014. Risiko Pendidikan Ibu terhadap Kejadian Stunting pada Anak 6-23 Bulan. Panel Gizi Makan, Volume 37(2): 129-136.

Rohimah, I., Etti, S., Ernawati, N.(2014). Analisis energi dan protein serta daya terima biscuit tepung labu kuning dan ikan lele. Jurnal USU, Ac.id/ index. php/gkre/article/viewfile/5160/2781.

Rosa, R., Bandara, N.M., \& Nunes, M.I.(2007). Nutritional quality of African cat fish Clarias gariepinus (Burchell 1822):A positive criterion for the future developmant of Siluroidei, Journal Food Science and Technology 42:342-351.

Singh, A., Kumar, A. \& Kaushalendra, U., 2017. Birth Size, Stunting and Recovery from Stunting in Andhra Pradesh, India: Evidence from the Young Live Study. Maternal and Child Health Journal, Volume 21(3): 492-508. https://doi.org/10.1007/s10995-016-2132-8

Peraturan Menteri Kesehatan Republik Indonesia Nomor 3 Tahun 2014 Tentang Sanitasi Total Berbasis Masyarakat. 